\title{
Enzyme inhibitory and antioxidant activities of traditional medicinal plants: Potential application in the management of hyperglycemia
}

\author{
Vandana Gulati, lan H Harding and Enzo A Palombo*
}

\begin{abstract}
Background: Traditional Indian and Australian medicinal plant extracts were investigated to determine their therapeutic potential to inhibit key enzymes in carbohydrate metabolism, which has relevance to the management of hyperglycemia and type 2 diabetes. The antioxidant activities were also assessed.

Methods: The evaluation of enzyme inhibitory activity of seven Australian aboriginal medicinal plants and five Indian Ayurvedic plants was carried out against a-amylase and a-glucosidase. Antioxidant activity was determined by measuring (i) the scavenging effect of plant extracts against 2, 2-diphenyl-1-picryl hydrazyl (DPPH) and 2, 2'azinobis-3-ethylbenzothiazoline-6-sulfonate (ABTS) and (ii) ferric reducing power. Total phenolic and total flavonoid contents were also determined.

Results: Of the twelve plant extracts evaluated, the highest inhibitory activity against both a-amylase and aglucosidase enzymes was exerted by Santalum spicatum and Pterocarpus marsupium with $\mathrm{IC}_{50}$ values of $5.43 \mu \mathrm{g} / \mathrm{ml}$ and $0.9 \mu \mathrm{g} / \mathrm{ml}$, respectively, and $5.16 \mu \mathrm{g} / \mathrm{ml}$ and $1.06 \mu \mathrm{g} / \mathrm{ml}$, respectively. However, the extracts of Acacia ligulata $\left(\mid C_{50}=1.01 \mu \mathrm{g} / \mathrm{ml}\right)$, Beyeria leshnaultii $(0.39 \mu \mathrm{g} / \mathrm{ml})$, Mucuna pruriens $(0.8 \mu \mathrm{g} / \mathrm{ml})$ and Boerhaavia diffusa $(1.72 \mu \mathrm{g} / \mathrm{ml})$ exhibited considerable activity against a-glucosidase enzyme only. The free radical scavenging activity was found to be prominent in extracts of Acacia kempeana, Acacia ligulata followed by Euphorbia drummondii against both DPPH and ABTS. The reducing power was more pronounced in Euphorbia drummondii and Pterocarpus marsupium extracts. The phenolic and flavonoid contents ranged from 0.42 to $30.27 \mu \mathrm{g} / \mathrm{mg}$ equivalent of gallic acid and 0.51 to $32.94 \mu \mathrm{g} / \mathrm{mg}$ equivalent of quercetin, respectively, in all plant extracts. Pearson's correlation coefficient between total flavonoids and total phenolics was 0.796 .
\end{abstract}

Conclusion: The results obtained in this study showed that most of the plant extracts have good potential for the management of hyperglycemia, diabetes and the related condition of oxidative stress.

Keywords: Anti-diabetic, Enzyme inhibition, Antioxidant

\section{Background}

Diabetes mellitus is an important metabolic syndrome. The increasing worldwide incidence of diabetes mellitus in adults constitutes a global public health burden. The World Health Organization (WHO) estimates that currently more than 180 million people worldwide have diabetes and it is likely to double by 2030, with India, China and United States predicted to have the largest

\footnotetext{
* Correspondence: epalombo@swin.edu.au

Environment and Biotechnology Centre, Faculty of Life and Social Sciences, Swinburne University of Technology, PO Box 218, Hawthorn 3122 VIC, Australia
}

number of affected individuals [1,2]. Many plants and their active chemical compounds have demonstrated activity in the treatment of various disorders [3]. According to ethnobotanical information, more than 800 plants are used as traditional remedies in one or other form for the treatment of diabetes [4]. The management of diabetes without any side effects is still a challenge; therefore plants continue to play an important role in the discovery of new compounds for the treatment of this disease.

The management of diabetes can be achieved by reducing post-prandial hyperglycemia by delaying the 
activities of the enzymes $\alpha$-amylase and $\alpha$-glucosidase which are responsible for the digestion of carbohydrates and absorption of glucose in the digestive tract, respectively $[5,6]$. Drugs derived from natural products have played a major role in the development of pharmaceutical treatments for diabetes. Metformin, the single most prescribed agent for the treatment of diabetes, originated from herbal medicine $[7,8]$. A plant-derived antidiabetic agent, galegine, was isolated from Galega officinalis. Experimental and clinical evaluations provided the pharmacological and chemical basis for the subsequent discovery of metformin [7,9]. 1- deoxynojirimycin (DNJ), a potent $\alpha$-glucosidase Inhibitor, was isolated from the water extract of leaves of the mulberry tree (Morus alba L.) $[10]$.

There are many cellular biochemical pathways and environmental toxins which produce reactive oxygen species (ROS) [11] and contribute to the development of diseases such as cancer, cardiovascular disorders, diabetes, cataracts and many neurodegenerative diseases [12]. Many studies have confirmed that plants and foods rich in polyphenolic content are effective scavengers of free radicals, thus helping in the prevention of these diseases through their antioxidant activity [13]. Antioxidants which are present in plants, herbs and dietary sources help in preventing vascular diseases in diabetic patients [14]. Tannins and flavonoids are the secondary metabolites in plants considered to be the natural source of antioxidants which prevent destruction of $\beta$-cells and diabetes-induced ROS formation [15]. Thus, it is a good strategy to manage diabetes as a whole with plants which show good enzyme inhibitory and antioxidant activities [16]. Therefore, the aim of our study was to screen some traditional Australian aboriginal plants and Ayurvedic Indian plant extracts to determine those which showed promising enzyme inhibitory and antioxidant activities.

\section{Methods}

Plants

The Australian aboriginal plants were selected on the basis of availability and their known medicinal activities. The Indian Ayurvedic plants were selected according to their reported anti-diabetic potential. These plants were known to possess anti-diabetic action and but not all plants had been screened using enzymatic inhibition assays used in this study. Seven Australian aboriginal medicinal plant extracts were obtained from the University of South Australia, Adelaide, Australia. Powdered extracts of five Indian Ayurvedic plants were provided by Promed Research Centre, Gurgaon, India. Table 1 shows the ethnobotanical uses of the plants used in this study. Many of the plants screened here have been used as food or food supplements, suggesting that they are safe to take orally. Seeds and gums of Acacia species are edible and, as this plant grows in harsh environments, it is commonly known as "dead finish", Santalum lanceolatum (SL) has sweet fruits which are eaten fresh and the decoction of the inner bark of S. spicatum (SS) was drunk to get relief from coughs [17]. Fruits of Eugenia jambolana (EJ), called blackberries in English, are eaten fresh, are rich in polyphenols, are widely distributed in India and are known to reduce glucose [18]. Seeds of Mucuna pruriens (MP), also known as velvet beans, are cooked or can be eaten raw [19] and in Central America the roasted and ground seeds are used as a substitute for coffee [20]. Tuberous roots of Curculigo orchioides (CO) are eaten to maintain vitality, strength and have aphrodisiac effects [21]. Tribal people of West Bengal eat Boerrhaavia diffusa (BD) as a vegetable, while in the

Table 1 Traditional uses of Australian aboriginal and Indian Ayurvedic plants used in this study

\begin{tabular}{|c|c|c|c|}
\hline Plant & Family & Use & References \\
\hline Acacia kempeana F. Muell. & Mimosaceae & Chest infection, severe cold, general sickness & {$[23,24]$} \\
\hline Acacia. tetragonophylla F. Muell. & Mimosaceae & Cough, treatment of circumcision wounds, dysentery & {$[25]$} \\
\hline Acacia ligulata Cunn. ex Benth. & Mimosaceae & Cough, cold, chest infection, general illness & {$[24,26,27]$} \\
\hline Beyeria lechenaultii (DC.) Baillon & Euphorbiaceae & General sickness, fever & {$[26]$} \\
\hline Euphorbia drummondii Boiss. & Euphorbiaceae & Skin sores, genital sores, fever, dysentery & {$[23]$} \\
\hline Santalum lanceolatum $\mathrm{R} . \mathrm{Br}$. & Santalaceae & Cold, malaise, sore throat, venereal diseases, painful urination & {$[23]$} \\
\hline Santalum spicatum (R. Br.) A. DC. & Santalaceae & Cough & {$[26]$} \\
\hline Boerhaavia diffusa Linn. & Nyctaginaceae & $\begin{array}{l}\text { Diuretic, anti-inflammatory, antifibrinolytic, anticonvulsant, antibacterial, } \\
\text { antihepatotoxic, antidiabetic }\end{array}$ & {$[22,28]$} \\
\hline Curculigo orchioides Gaertn. & Amaryllidaceae & Demulscent, diuretic, aphrodisiac, asthma, jaundice, hepatoprotective & {$[21,29]$} \\
\hline Eugenia jambolana Lam. & Myrtaceae & Bronchitis, asthma, sore throat, diabetes, dysentery, antibacterial, antioxidant & {$[18,30,31]$} \\
\hline Mucuna Pruriens Linn. & Leguminoseae & $\begin{array}{l}\text { Anti-parkinson, hypoglycemic, hypo-cholestrolemic, antioxidant, antitumour, } \\
\text { antimicrobial }\end{array}$ & {$[32,33]$} \\
\hline Pterocarpus marsupium Roxb. & Fabaceae & Antidiabetic, anticataract, cardiotonic, hepatoprotective & {$[32,34]$} \\
\hline
\end{tabular}


Assam state of India, this plant is also cooked and eaten [22].

\section{Preparation of extracts}

The preparation of Australian aboriginal plants extracts and information about voucher specimens have previously been described [23]. The Indian Ayurvedic plants were provided as dried powders by Promed Research Centre, India, with the following batch codes: PROM/ PTMA-01 (PM), PROM/BD-43 (BD), PROM/CUOR-15 (CO), PROM/EUJA-10 (EJ) and PROM/MUPR-05 (MP). Five grams of powder were soaked overnight in $50 \mathrm{ml}$ ethanol and filtered with Whatmann filter paper No. 1. The filtrates were concentrated in vacuo in a rotary evaporator at $55^{\circ} \mathrm{C}$ and reconstituted in ethanol at $250 \mu \mathrm{g} / \mu \mathrm{l}$ as a stock solution which was used to make working solutions of various concentrations. Enzymes and chemicals ( $\alpha$-amylase enzyme from porcine pancreas, yeast $\alpha$-glucosidase, acarbose, $p$-nitro phenyl glucopyranoside (p-NPG) and 1,1-diphenyl-2-picrylhydrazyl radical (DPPH), 2,2'-azinobis-3-ethylbenzothiazoline-6sulfonate (ABTS), butylated hydroxyl toluene (BHT), potassium ferricyanide, trichloroacetic acid, ascorbic acid, ferric chloride, Folin-Ciocalteu reagent, quercetin, gallic acid and aluminium chloride were purchased from Sigma-Aldrich, Australia.

\section{Amylase inhibition screening assay}

The $\alpha$-amylase inhibitory assay was modified from Correia et al. [35]. Twenty $\mu \mathrm{l}$ of porcine pancreatic $\alpha$ amylase solution (EC 3.2.1.1; equivalent to $3000 \mathrm{U}$ in $50 \mathrm{mM}$ phosphate buffer, $\mathrm{pH}$ 6.9) were mixed with $15 \mu \mathrm{l}$ of plant extract and incubated at $37^{\circ} \mathrm{C}$ for 45 minutes. After incubation, the plant - enzyme mixture was applied to a sterile paper disc and placed onto the center of petri plates containing medium consisting of $1 \%(\mathrm{w} / \mathrm{v})$ agar and $1 \%(\mathrm{w} / \mathrm{v})$ starch in distilled water. Plates were allowed to stand for 3 days at $25^{\circ} \mathrm{C}$ then stained with iodine and allowed to stand for $15 \mathrm{~min}$. The diameter of the clear zone was measured and used to calculate the amylase inhibitory activity. As a control, the enzyme was mixed with the solvent in which the plants were extracted (ethanol) and applied onto the sterile disc. Results were expressed as percentage (\%) amylase inhibition = $\{$ (diameter of control - diameter of sample)/diameter of the control\} $\times 100$.

Amylase inhibition assay by quantitative starch hydrolysis The $\alpha$-amylase inhibitory activity was determined [36] using porcine pancreatic $\alpha$-amylase solution (EC 3.2.1.1) type VI B. To $125 \mu \mathrm{l}$ of different plant extract concentrations (range $1.56 \mu \mathrm{g} / \mathrm{ml}$ to $500 \mu \mathrm{g} / \mathrm{ml}$ ), $\alpha$-amylase solution $(0.5 \mathrm{mg} / \mathrm{ml}$ in $0.02 \mathrm{M}$ sodium phosphate buffer) was mixed and the reaction mixture was pre-incubated for 10 minutes at room temperature. After pre-incubation, $25 \mu \mathrm{l}$ of $1 \%(\mathrm{w} / \mathrm{v})$ starch solution were added every $5 \mathrm{sec}-$ onds for a total of $125 \mu \mathrm{l}$. The reaction mixture was again incubated for 10 minutes at room temperature. The reaction was terminated by adding $250 \mu \mathrm{l}$ of 3, 5-dinitro salicylic acid reagent. The tubes were placed in boiling water bath for 5 minutes and then cooled at room temperature. The reaction mixture was diluted by adding $5000 \mu \mathrm{l}$ of distilled water. The generation of maltose was quantified by measuring the absorbance at $540 \mathrm{~nm}$ of 3-amino-5nitrosalicylic acid (from reduction of 3, 5-dinitrosalicylic acid [37]) using a UV-visible spectrophotometer. The control was buffer treated in the same way as plant samples. The standard used was acarbose (concentration range $1.56 \mu \mathrm{g} / \mathrm{ml}$ to $500 \mu \mathrm{g} / \mathrm{ml})$. Results were expressed as percentage $(\%)$ amylase inhibition $=\{$ (absorbance of control $_{540 \mathrm{~nm}}-$ absorbanceof samples $_{540 \mathrm{~nm}}$ )/absorbance of the control $540 \mathrm{~nm}\} \times 100$.

\section{Glucosidase inhibition assay}

The $\alpha$-glucosidase inhibition assay was modified from Apostolidis et al. [38] using yeast $\alpha$-glucosidase (EC 2328898). A volume of $25 \mu \mathrm{l}$ of plant extract (range $0.35 \mu \mathrm{g} / \mathrm{ml}$ to $100 \mu \mathrm{g} / \mathrm{ml}$ ) was mixed with $50 \mu \mathrm{l}$ of $\alpha$ glucosidase enzyme $(0.1 \mathrm{U} / \mathrm{ml}$ in $0.1 \mathrm{M}$ potassium phosphate buffer solution, pH 6.9) in 96 well plates and incubated at $37^{\circ} \mathrm{C}$ for 30 minutes. After pre-incubation, $25 \mu \mathrm{l}$ of $5 \mathrm{mM}$ pNPG in $0.1 \mathrm{M}$ phosphate buffer were added to each well and the reaction mixture was incubated again at $37^{\circ} \mathrm{C}$ for 30 minutes. Thirty $\mu \mathrm{l}$ of $0.1 \mathrm{M}$ sodium carbonate solution were added to the above reaction mixture and incubated again for 20 minutes at $37^{\circ} \mathrm{C}$. Before and after incubation, the absorbance was measured at $405 \mathrm{~nm}$ and compared to the control that contained $25 \mu \mathrm{l}$ of buffer solution instead of plant extract. The standard used was acarbose (concentration range $0.35 \mu \mathrm{g} / \mathrm{ml}$ to $100 \mu \mathrm{g} / \mathrm{ml})$. The $\alpha$-glucosidase activity was determined by measuring release of $\mathrm{p}$-nitrophenol from p-nitrophenyl $\alpha$-D-glucopyranoside [39]. The $\alpha$ glucosidase inhibitory activity was expressed as

$$
\begin{aligned}
& \text { Percentage }(\%) \text { inhibition } \\
& =\left\{\left(\text { absorbance of } \text { control }_{405 \mathrm{~nm}}\right.\right. \\
& \left.\quad-\text { absorbance of samples }_{405 \mathrm{~nm}}\right) \\
& \left.\quad \text { /absorbance of the control } \mathrm{a}_{405 \mathrm{~nm}}\right\} \times 100
\end{aligned}
$$

\section{Total phenolic content assay}

The total phenolic content was quantified using a modified version of the assay described by Singleton et al. [40] using Folin-Ciocalteu reagent. Twenty $\mu \mathrm{l}$ of plant sample or gallic acid (standard phenolic compound) were diluted with $1580 \mu \mathrm{l}$ of distilled water and then 
mixed with $100 \mu \mathrm{l}$ of $2 \mathrm{~N}$ Folin-Ciocalteu reagent. The mixture was shaken and kept for 6 minutes, after which $300 \mu \mathrm{l}$ of $5 \%$ aqueous $\mathrm{Na}_{2} \mathrm{CO}_{3}$ solution were added and mixed properly. The mixture was incubated for 2 hours at $20^{\circ} \mathrm{C}$. The absorbance was measured for all the samples at $765 \mathrm{~nm}$. A standard curve was prepared using $25-1000 \mathrm{mg} / \mathrm{l}$ of gallic acid. The total phenolic values were expressed in terms of gallic acid equivalents $(\mu \mathrm{g} /$ mg of dry mass). The blank (distilled water) was treated in the same way as the samples and the dilution factor was taken into account for the samples where dilution was performed.

\section{Determination of total flavonoids}

The total flavonoids were determined using a modification of the assay described by Dixit et al. [41]. Plant samples $(250 \mu \mathrm{l})$ were diluted with $1250 \mu \mathrm{l}$ of distilled water and $75 \mu \mathrm{l}$ of $5 \% \mathrm{NaNO}_{2}$ were added to the sample together with $150 \mu \mathrm{l}$ of $10 \%$ aluminum chloride. After mixing and incubation for 5 minutes, $500 \mu \mathrm{l}$ of $1 \mathrm{M}$ $\mathrm{NaOH}$ were added to the reaction mixture and a total volume of $2500 \mu \mathrm{l}$ was made up with distilled water. Following vigorous mixing, the absorbance was measured at $510 \mathrm{~nm}$. A standard curve was prepared using 25$1000 \mathrm{mg} / \mathrm{l}$ of quercetin. Results were expressed as $\mu \mathrm{g}$ of quercetin equivalents per milligram of dry mass of the plant extract.

\section{Antioxidant activity determined by 1, 1-diphenyl-2- picrylhydrazyl (DPPH) radical inhibition}

The DPPH scavenging activity was determined by an assay modified from Kwon et al. [42]. To $150 \mu \mathrm{l}$ of $0.1 \mathrm{mM}$ DPPH in methanol, a volume of $50 \mu \mathrm{l}$ of plant extract (range 20 to $1000 \mu \mathrm{g} / \mathrm{ml}$ ) was mixed and kept in the dark at room temperature for 60 minutes. After incubation, the absorbance was recorded at $490 \mathrm{~nm}$. The results were compared with the control which contained $50 \mu \mathrm{l}$ of ethanol instead of plant extracts. The positive controls were butyl hydroxyl toluene (BHT) and ascorbic acid in concentration range 3.12 to $250 \mu \mathrm{g} / \mathrm{ml}$. The antioxidant activity was expressed aspercentage $(\%)$ inhibition $=\{$ (absorbance of

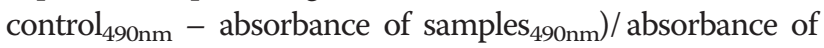
the control $\left._{490 \mathrm{~nm}}\right\} \times 100$.

\section{Antioxidant activity determined by 2,2 '-azinobis-3-} ethylbenzothiazoline-6-sulfonate (ABTS) radical inhibition The free radical scavenging activity of plant extracts was also studied using the ABTS radical cation. The decolorization assay is based on reduction of the ABTS $+\cdot$ radical by plant extracts having antioxidant capacity [43]. ABTS radical was dissolved in deionized water to make a $7 \mathrm{mM}$ solution and $2.45 \mathrm{mM}$ potassium persulfate solution was added to the same. To produce the ABTS free radical cation, the mixture was allowed to stand in dark at room temperature for 12 to 16 hours. The free radical solution of ABTS was diluted with ethanol to an absorbance of 0.7 at $734 \mathrm{~nm}$ for the assay. To $990 \mu \mathrm{l}$ of ABTS free radical solution, a volume of $10 \mu \mathrm{l}$ of plant extract (range 1 to $1000 \mu \mathrm{g} / \mathrm{ml}$ ) was mixed and kept in the dark at room temperature for 60 minutes. After incubation, the absorbance was recorded at $734 \mathrm{~nm}$. The results were compared with the control which contained $10 \mu \mathrm{l}$ of ethanol instead of plant extracts. The positive controls were $\mathrm{BHT}$ and ascorbic acid in concentration range 1.56 to $250 \mu \mathrm{g} / \mathrm{ml}$. The antioxidant activity was expressed as

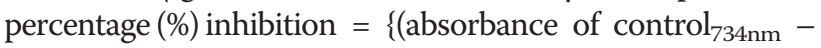
absorbance of samples $734 \mathrm{~nm}) /$ absorbance of the con$\left.\operatorname{trol}_{734 \mathrm{~nm}}\right\} \times 100$.

\section{Ferric reducing power assay}

The ferric reducing power assay was carried out as described by Fawole et al. [44] using $30 \mu$ l plant extracts and standards (BHT and ascorbic acid) of different concentrations (range 25 to $1000 \mu \mathrm{g} / \mathrm{ml}$ ) added to 96 well plates along with $40 \mu \mathrm{l}$ of $0.2 \mathrm{M}$ potassium phosphate buffer $(\mathrm{pH}$ 7.2) and $40 \mu \mathrm{l}$ of potassium ferricyanide $(1 \% \mathrm{w} / \mathrm{v})$. The reaction mixtures were incubated at $50^{\circ} \mathrm{C}$ for 20 minutes. After incubation, $40 \mu \mathrm{l}$ of trichloroacetic acid $(10 \% \mathrm{w} / \mathrm{v}), 150 \mu \mathrm{l}$ distilled water and $30 \mu \mathrm{l}$ of ferric chloride $(0.1 \% \mathrm{w} / \mathrm{v})$ were added and the reaction mixture again incubated for 30 minutes at room temperature in the dark. Absorbance was recorded at $630 \mathrm{~nm}$ using a microplate reader and the positive controls were BHT and ascorbic acid whereas the negative control was buffer. The absorbance of each sample was plotted against concentration and compared with the standards.

\section{Statistical analysis}

All samples were analyzed in triplicate. Data are presented as mean \pm standard error mean (SEM). Differences were evaluated by one-way analysis of variance (ANOVA) test completed by a Bonferroni's multicomparison test. Differences were considered significant at $\mathrm{p}<0.01$. The concentration giving $50 \%$ inhibition $\left(\mathrm{IC}_{50}\right)$ was calculated by non-linear regression with the use of Graphpad Prism Version 5.0 for Windows (GraphPad Software, San Diego, CA, USA) (www. graphpad.com). The dose-response curve was obtained by plotting the percentage inhibition versus concentration [37].

\section{Results and discussion}

The inhibition of digestive enzymes, such as $\alpha$-amylase and $\alpha$-glucosidase, has been considered to be an effective strategy to control blood glucose. Agents based on natural products are particularly attractive as side effects are minimal and the therapies are well-tolerated compared to the other oral hypoglycemic agents currently available 
$[5,36]$. The present study was therefore designed to investigate the bioactive properties of twelve traditional medicinal plants relevant to the management of hyperglycemia and type 2 diabetes. These properties included inhibition of $\alpha$-amylase and $\alpha$-glucosidase enzymes and antioxidant potential. The total phenolic and total flavonoid contents of the extracts were also determined.

Type 2 diabetes is a global health challenge and the WHO has recommended research and use of complementary medicines for the management of this disease. Type 2 diabetes was previously considered as maturityonset diabetes but, due to increasing rates of obesity, there is an increasing risk of developing this disease in childhood $[45,46]$. The goal of treatment is to maintain normal levels of blood glucose and prevent the development of skin infections, diabetic nephropathy and cardiovascular disorders [47].

The results of preliminary agar diffusion amylase inhibition assays indicated that all of the Australian aboriginal plant extracts showed complete inhibition of $\alpha$ amylase enzyme such that no hydrolysis of starch was evident. Among the Indian Ayurvedic plant extracts, only Eugenia jambolana and Curculigo orchioides showed complete inhibition at $250 \mathrm{mg} / \mathrm{ml}$. Mucuna pruriens, Boerhaavia diffusa and Pterocarpus marsupium extracts showed partial inhibition. While the majority of the extracts demonstrated potent $\alpha$-amylase inhibiting activity, some of the Australian plant extracts were particularly active (Acacia ligulata and Acacia tetragonophylla) and showed activity at concentrations lower than those of the other extracts.

In the amylase assay (Figure 1A), the positive control acarbose showed an $\mathrm{IC}_{50}$ of $7.81 \mu \mathrm{g} / \mathrm{ml}$ and the Australian plant extracts which exerted higher amylase inhibitory activity were SS $(5.53 \mu \mathrm{g} / \mathrm{ml}), \mathrm{AL}, \mathrm{BL}$ and SL. We did not observe similar activity with extracts of Acacia tetragonophylla (AT), Euphorbia drumondii (ED) and Acacia kempeana (AK) which showed $\mathrm{IC}_{50}$ values in the range 32 to $66 \mu \mathrm{g} / \mathrm{ml}$. The same plant extracts showed statistically significant low $\mathrm{IC}_{50}$ (in the range 0.48 to $1.83 \mu \mathrm{g} / \mathrm{ml})$ as compared to acarbose $(4.41 \mu \mathrm{g} / \mathrm{ml})$ for glucosidase inhibition (Figure 2A).

For amylase inhibition, among the five Indian plant extracts screened, only PM extract showed a lower, but not statistically significant, $\mathrm{IC}_{50}$ of $5.16 \mu \mathrm{g} / \mathrm{ml}$ compared to acarbose (Figure 1B). EJ, CO and MP extracts showed $\mathrm{IC}_{50}$ in the range 12.01 to $42.81 \mu \mathrm{g} / \mathrm{ml}$. Only MP and PM extracts showed statistically significant lower $\mathrm{IC}_{50}$ value for glucosidase inhibition as compared to acarbose (Figure 2B).

DPPH is a radical, purple in colour, which is reduced to the yellow coloured diphenylpicrylhydrazine by plant extracts. This antioxidant assay is based on the reduction of alcoholic DPPH solution in the presence of

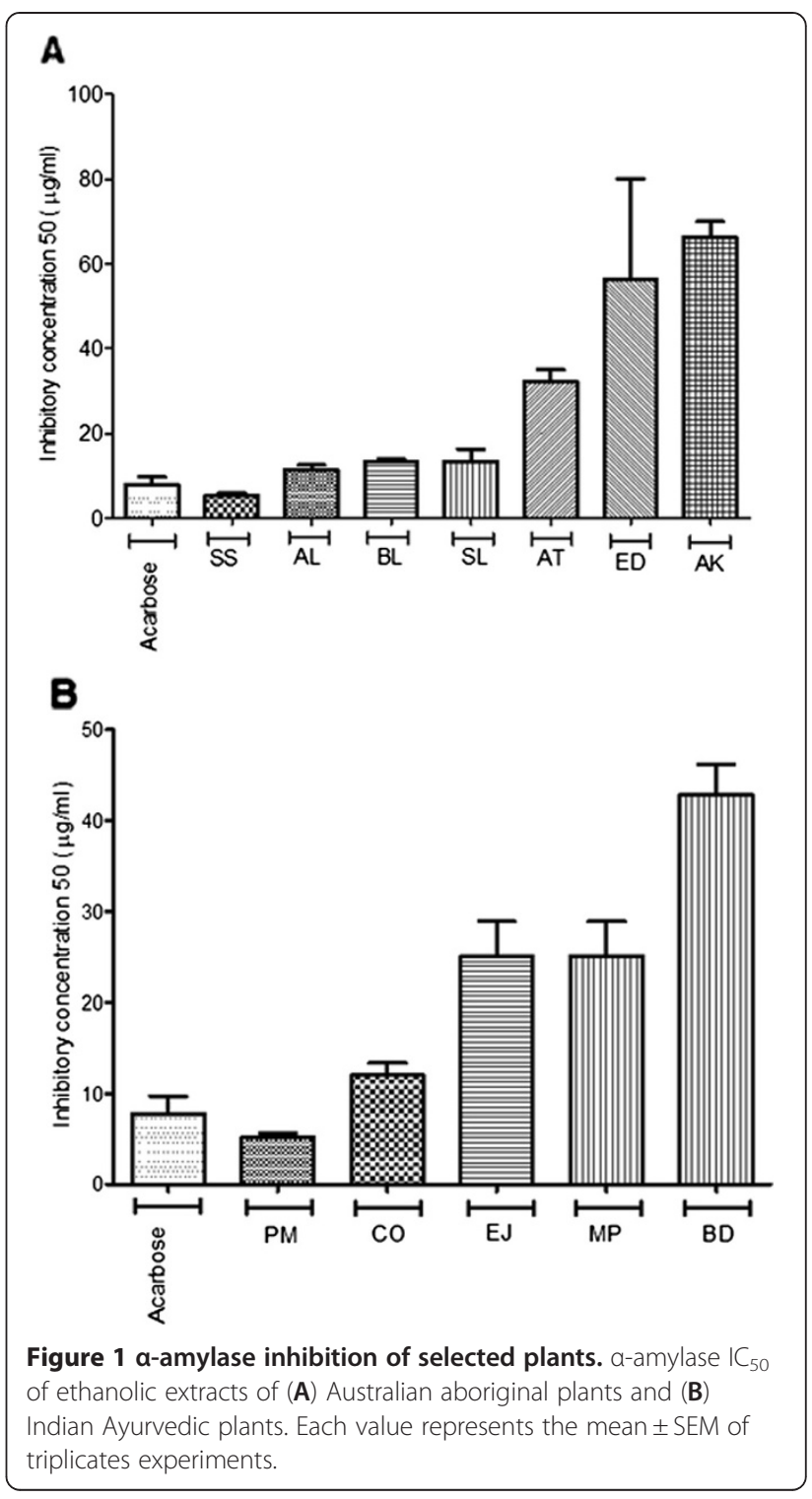

hydrogen-donating antioxidant due to the formation of the non-radical form, DPPH-H [48].

The positive controls, ascorbic acid and BHT, were used for DPPH, ABTS and ferric reducing power assays. $\mathrm{IC}_{50}$ values (Figure $3 \mathrm{~A}$ and $3 \mathrm{~B}$ ) were calculated for all the extracts and controls and were found to be 12.37 and $41.82 \mu \mathrm{g} / \mathrm{ml}$ for ascorbic acid and BHT, respectively. Among the Australian plant extracts, AL showed nearly half the $\mathrm{IC}_{50}$ value of $6.98 \mu \mathrm{g} / \mathrm{ml}$ whereas the rest of the plant extracts exerted similar $\mathrm{IC}_{50}$ to that of ascorbic acid with AT having a five-fold higher $\mathrm{IC}_{50}$ value. The Indian plant extracts exerted $\mathrm{IC}_{50}$ in range 97 to $883 \mu \mathrm{g} / \mathrm{ml}$.

ABTS is a stable free radical, bluish-green in colour and the antioxidant assay is based on the reduction of 


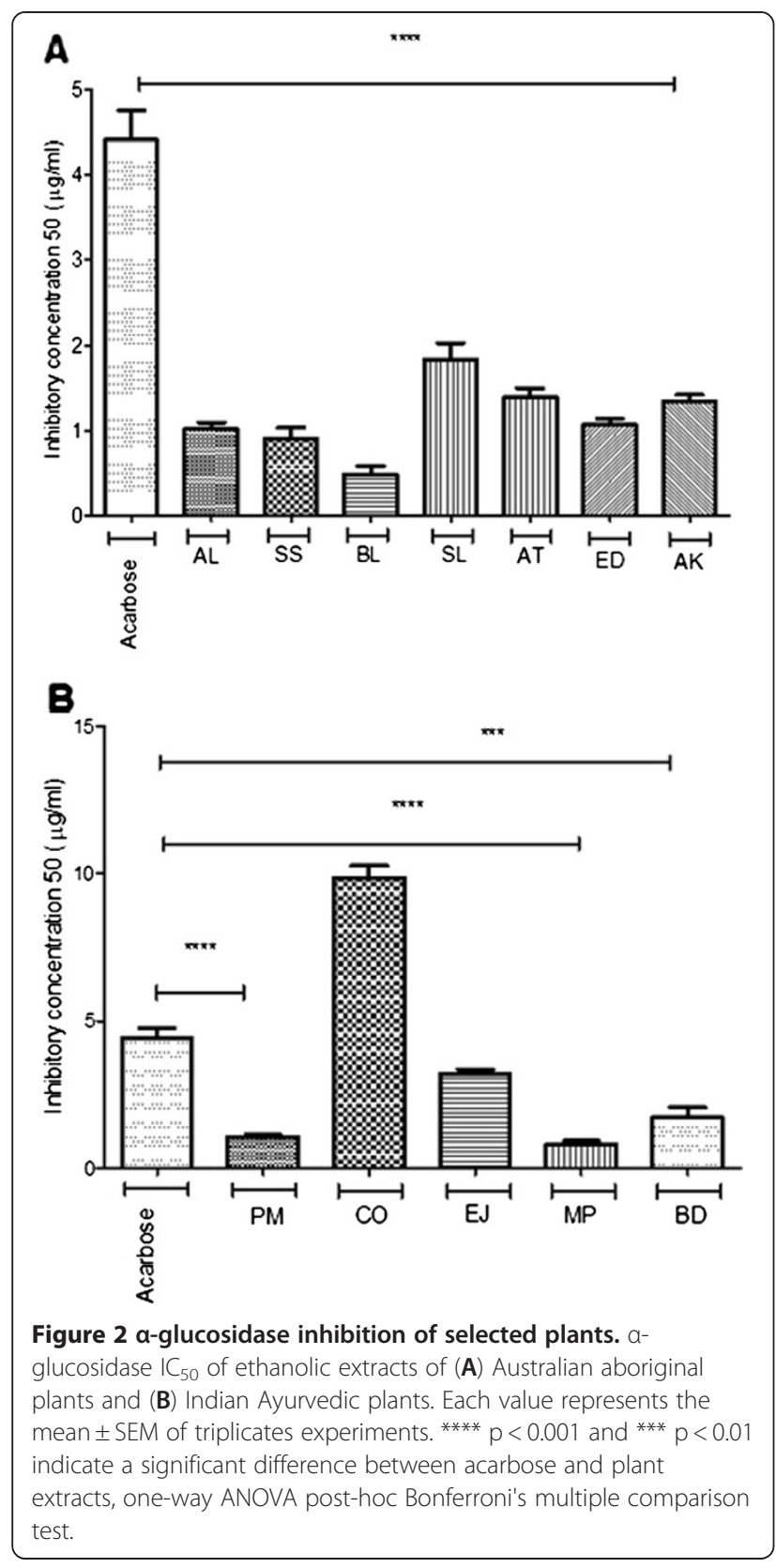

ABTS solution by plant extracts. $\mathrm{IC}_{50}$ values (Figure $4 \mathrm{~A}$ and $4 \mathrm{~B}$ ) for positive controls, ascorbic acid and BHT, were found to be 30.20 and $88.24 \mu \mathrm{g} / \mathrm{ml}$, respectively. Out of seven Australian plant extracts screened for ABTS radical scavenging activity, AK showed significantly lower $\mathrm{IC}_{50}$ as compared to BHT. Barring SL and AT, the rest of the plant extracts tested showed $\mathrm{IC}_{50}$ value equal or less than the positive controls tested. The five Indian plant extracts tested failed to show any significant activity as compared to positive controls and the $\mathrm{IC}_{50}$ value was in the range from 195.96 to $374.70 \mu \mathrm{g} / \mathrm{ml}$.

Antioxidant activities of these plant extracts were assessed through their ability to reduce the $\mathrm{Fe}^{3}$

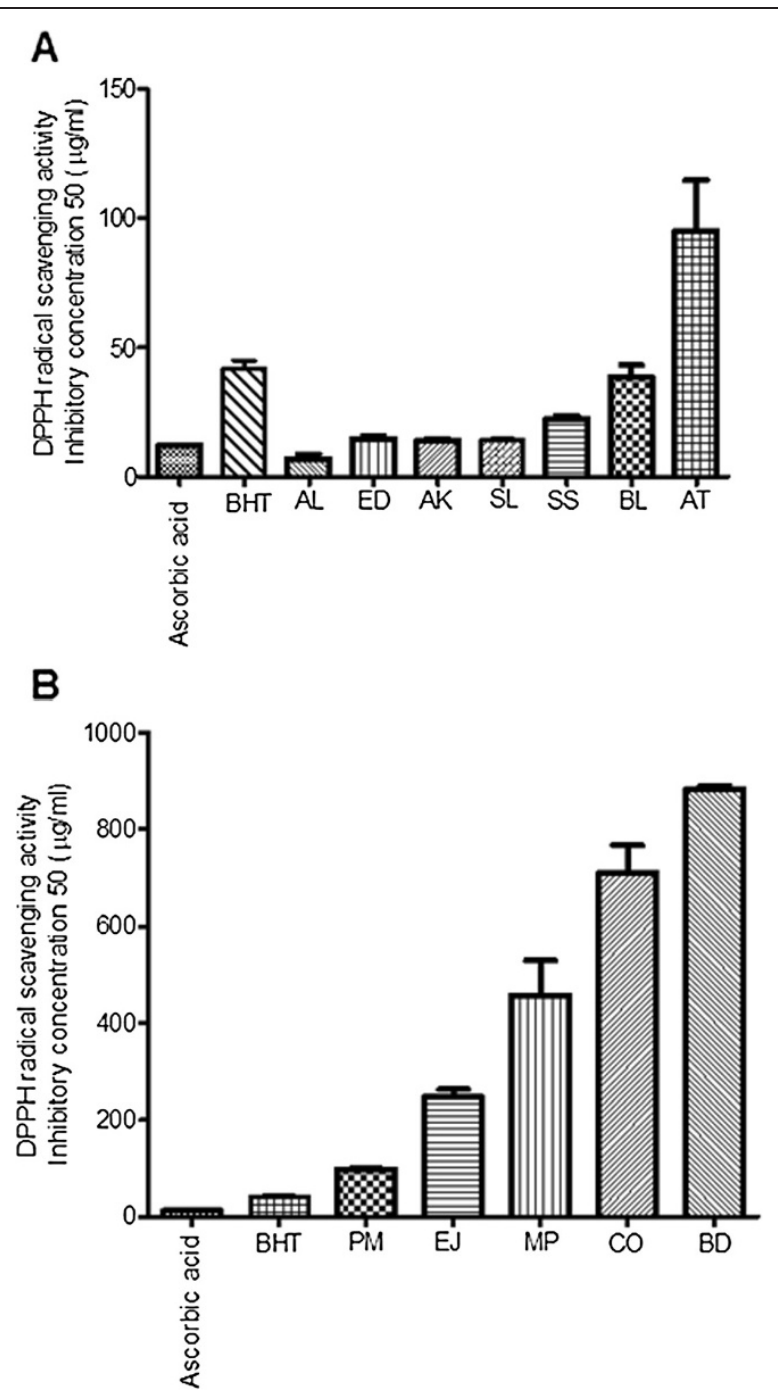

Figure 3 DPPH radical scavenging activity of selected plants.

DPPH radical scavenging $I_{50}$ of ethanolic extracts of $(\mathbf{A})$ Australian aboriginal plants and (B) Indian Ayurvedic plants. Each value represents the mean \pm SEM of triplicates experiments.

+/ferricyanide complex to the ferrous $\left(\mathrm{Fe}^{2+}\right)$ form. The ferrous ion was monitored by measuring the formation of Perl's Prussian blue at $630 \mathrm{~nm}$ [49]. Figure 5 presents the dose-dependent ferric-reducing powers of the sample extracts, ascorbic acid and BHT. The reducing power of ED extract showed similar activity to BHT but higher than ascorbic acid. Among the Indian plant extracts, PM showed good potential whereas $\mathrm{BD}$ and $\mathrm{CO}$ showed moderate activity. Overall, it was seen that most of the extracts possessed promising antioxidant activity.

Gallic acid and hydroxycinnamic acids are the phenolic acids found commonly in plants. Plants which contain high levels of phenolics are considered a good source of antioxidants and therefore it is important to 


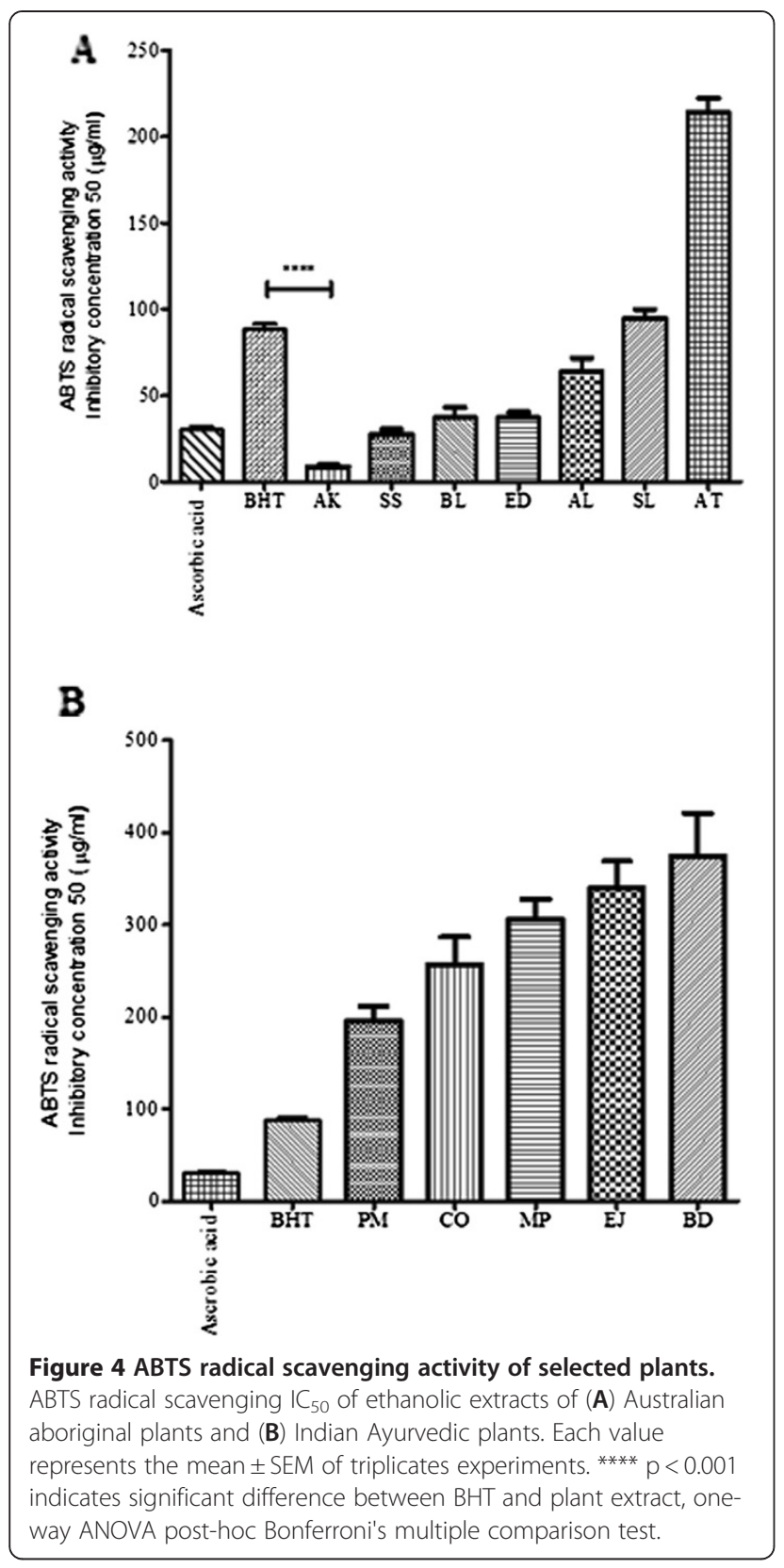

quantify the total phenolics and total flavonoids in plant extracts as they might have some beneficial effects on health [50]. The colorimetric assays used here are based on the chemical reduction of a reagent. For the extracts tested in this study, total phenolic content ranged from $0.42-30.27 \mu \mathrm{g} / \mathrm{mg}$ gallic acid and total flavonoids ranged from $0.51-32.94 \mu \mathrm{g} / \mathrm{mg}$ quercetin equivalents (Table 2). Pearson's correlation coefficient between total flavonoids and total phenolic was 0.796 .

Although there are scientific reports about antidiabetic activities of many Indian plants, there are no such studies on the activity of Australian plants with respect to diabetes. The Australian medicinal plants
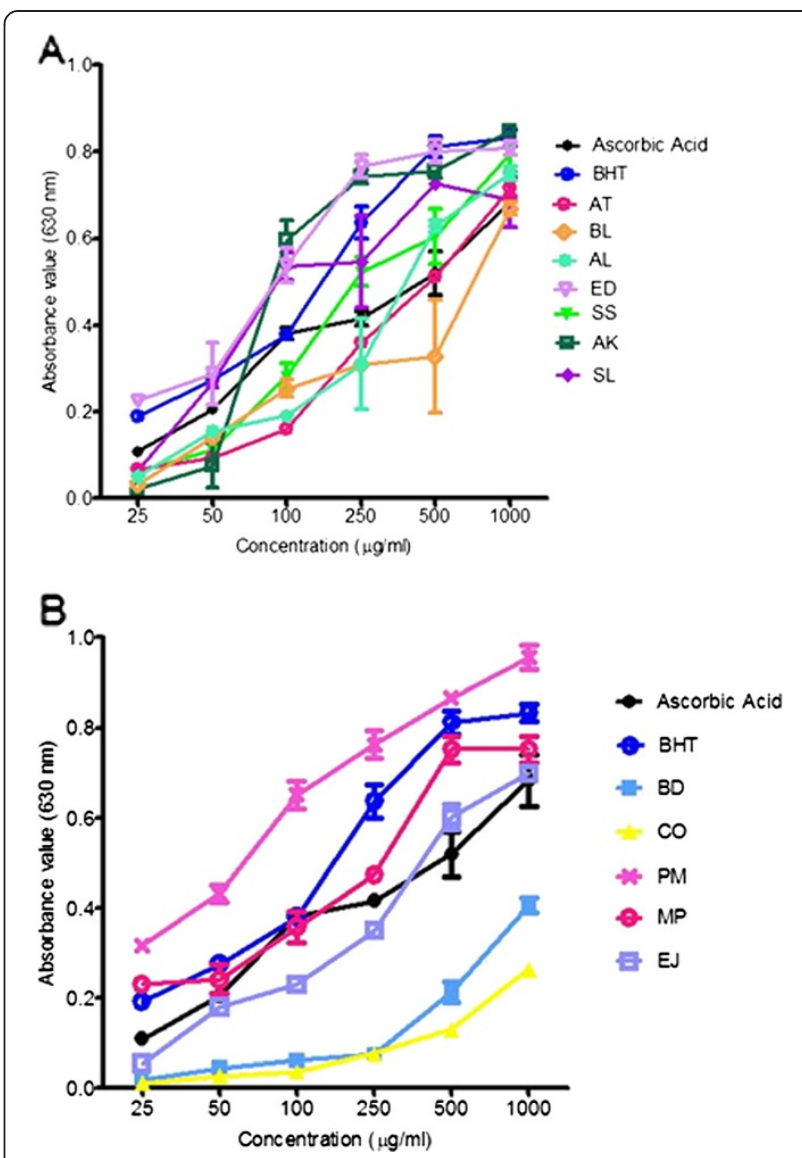

Figure 5 Ferric ion reducing power activity of selected plants. Ferric ion-reducing power of extracts of (A) Australian aboriginal plants and (B) Indian Ayurvedic plants ethanolic extracts, showing a dose-dependent linear increase in absorbance. Each value represents the mean \pm SEM of triplicates experiments.

investigated in this study (SS, AL, ED, BL, AK, AT and $\mathrm{SL}$ ) have been used for general illness, cold, cough and pain [23]. However, this is the first study to assess the potential of Australian traditional medicinal plants to be used in the management of hyperglycemia and diabetes. The traditional hunter-gatherer lifestyle and diet of Aboriginal people, which was high in carbohydrates, fibre, proteins and nutrients but low in fat and sugars, meant that cardiovascular diseases and diabetes were not common in these people. After the settlement of Europeans, the diet became Westernized with high sugar and fat content and the lack of essential nutrients, vitamins, minerals, proteins and fibre. This has increased the disease risk and these disorders are now prevalent in indigenous populations with the incidence of type 2 diabetes rapidly increasing [51,52].

Flavonoids, alkaloids and triterpenoids may be related to the anti-diabetic activity of plants. In particular, flavonoids are responsible for variety of pharmacological activities. For example, epicatechin is known to possess 
Table 2 Total phenolic and flavonoid contents for Australian aboriginal and Indian Ayurvedic plant extracts

\begin{tabular}{|c|c|c|}
\hline Plant extract & $\begin{array}{c}\text { TPC ( } \mu \mathrm{g} \mathrm{GAE} / \mathrm{mg} \\
\text { extract) }\end{array}$ & $\begin{array}{c}\mathrm{TFC}(\mu \mathrm{g} \mathrm{QE} / \mathrm{mg} \\
\text { extract) }\end{array}$ \\
\hline $\begin{array}{l}\text { Santalum spicatum } \\
\text { Acacia ligulata } \\
\text { Euphorbia } \\
\text { drummondii }\end{array}$ & $\begin{array}{l}0.87 \pm 0.11 \\
0.95 \pm 0.06 \\
0.93 \pm 0.01\end{array}$ & $\begin{array}{l}1.37 \pm 0.11 \\
1.52 \pm 0.36 \\
0.51 \pm 0.12\end{array}$ \\
\hline Beyeria leshnaultii & $0.42 \pm 0.038$ & $1.34 \pm 0.21$ \\
\hline Acacia kempeana & $1.47 \pm 0.075$ & $1.78 \pm 0.15$ \\
\hline $\begin{array}{l}\text { Acacia } \\
\text { tetragonophylla }\end{array}$ & $0.56 \pm 0.17$ & $0.94 \pm 0.13$ \\
\hline $\begin{array}{l}\text { Santalum } \\
\text { lanceolatum }\end{array}$ & $1.28 \pm 0.035$ & $1.35 \pm 0.18$ \\
\hline Eugenia jambolana & $28.31 \pm 0.22$ & $10.72 \pm 0.44$ \\
\hline Curculigo orchoides & $15.17 \pm 0.42$ & $22.18 \pm 0.43$ \\
\hline $\begin{array}{l}\text { Pterocarpus } \\
\text { marsupium }\end{array}$ & $30.27 \pm 0.88$ & $32.94 \pm 3.24$ \\
\hline $\begin{array}{l}\text { Boerhaavia diffusa } \\
\text { Mucuna pruriens }\end{array}$ & $\begin{array}{l}5.54 \pm 0.24 \\
5.83 \pm 0.57\end{array}$ & $\begin{array}{l}3.58 \pm 0.61 \\
13.25 \pm 3.7\end{array}$ \\
\hline
\end{tabular}

TPC - total phenolic content, TFC - total flavonoid content. GAE- gallic acid equivalent, QE- quercetin equivalent. The results are average of triplicate analysis $(n=3$; data expressed as mean $\pm S D$ ).

insulin-like properties, while epigallocatechin gallate is considered a promising hypoglycemic agent [53]. As shown in previous studies, the enzyme inhibition activity may be related to the polyphenolic content of the plant extract, however further studies are needed to confirm this.

\section{Conclusions}

The present study showed the anti-diabetic potential of a number of medicinal plant extracts. Most of the plants showed promise as agents for the management of hyperglycemia, along with good antioxidant activity. Indeed, the antioxidant and $\alpha$-amylase and $\alpha$-glucosidase inhibitory activities of plants and foods have been associated with their anti-diabetic activity $[42,54,55]$. Indian Ayurvedic plants have been previously reported to have antidiabetic properties; however limited data were available about the mechanism of action. Therefore, the plants should be further investigated as they may provide leads for the discovery of new drugs for the management of diabetes with minimal side effects.

\section{Competing interests}

The authors declare that they have no competing interests.

\section{Authors' contributions}

VG performed the experiments, evaluated the results and wrote the manuscript. IH and EP assisted in experimental design, evaluated the results and corrected the manuscript. Authors read and approved the final manuscript.

\section{Acknowledgements}

The authors gratefully acknowledge Dr Susan Semple (University of South Australia) and Dr Sateesh Chauhan (Promed Research Centre) for providing the extracts and dried powders, respectively. The authors acknowledge

Pankaj Gulati for his help in analyzing the data.

Received: 15 August 2011 Accepted: 7 June 2012

Published: 19 June 2012

\section{References}

1. Wild S, Roglic G, Green A, Sicree R, King H: Global Prevalence of Diabetes: Estimates for the year 2000 and projections for 2030. Diabetes Care 2004, 27(5):1047-1053.

2. Frode TS, Medeiros YS: Animal models to test drugs with potential antidiabetic activity. J Ethnopharmacol 2008, 115(2):173-183.

3. Palombo EA: Phytochemicals from traditional medicinal plants used in the treatment of diarrhoea: modes of action and effects on intestinal function. Phytother Res 2006, 20(9):717-724.

4. Alarcon-Aguilara FJ, Roman-Ramos R, Perez-Gutierrez S, Aguilar-Contreras A, Contreras-Weber CC, Flores-Saenz JL: Study of the anti-hyperglycemic effect of plants used as antidiabetics. J Ethnopharmacol 1998, 61(2):101-110

5. Ali H, Houghton PJ, Soumyanath A: Alpha-Amylase inhibitory activity of some Malaysian plants used to treat diabetes; with particular reference to Phyllanthus amarus. J Ethnopharmacol 2006, 107(3):449-455.

6. Bhandari MR, Jong-Anurakkun N, Hong G, Kawabata J: [alpha]-Glucosidase and [alpha]-amylase inhibitory activities of Nepalese medicinal herb Pakhanbhed (Bergenia ciliata, Haw.). Food Chem 2008, 106(1):247-252.

7. Bailey C, Day C: Metformin: its botanical background. Practical Diabetes International 2004, 21(3):115-117.

8. Day C: Are herbal remedies of use in diabetes? Diabet Med 2005, 22(s1):10-12.

9. Howlett HCS, Bailey CJ (Eds): Galegine and antidiabetic plants. Chichester, UK Wiley; 2007.

10. Asano N, Oseki K, Kaneko E, Matsui K: Enzymic synthesis of a- and $\beta$-Dglucosides of 1-deoxynojirimycin and their glycosidase inhibitory activities. Carbohydr Res 1994, 258:255-266.

11. Srinivasan R, Chandrasekar MJN, Nanjan MJ, Suresh B: Antioxidant activity of Caesalpinia digyna root. J Ethnopharmacol 2007, 113(2):284-291.

12. Marwah RG, Fatope MO, Mahroogi RA, Varma GB, Abadi HA, Al-Burtamani SKS: Antioxidant capacity of some edible and wound healing plants in Oman. Food Chem 2007, 101(2):465-470.

13. Nabavi SM, Ebrahimzadeha MA, Nabavi SF, Fazelian M, Eslami B: In vitro antioxidant and free radical scavenging activity of Diospyros lotus and Pyrus boissieriana growing in Iran. Pharmacogn Mag 2009, 5(18):122-126.

14. Buyukbalci A, Sedef Nehir El: Determination of in vitro antidiabetic effects, antioxidant activities and phenol contents of some herbal teas. Plant Foods Hum Nutr 2008, 63(1):27-33.

15. Aslan M, Orhan N, Orhan DD, Ergun F: Hypoglycemic activity and antioxidant potential of some medicinal plants traditionally used in Turkey for diabetes. J Ethnopharmacol 2010, 128(2):384-389.

16. Joshi N, Caputo GM, Weitekamp MR, Karchmer AW: Infections in Patients with Diabetes Mellitus. N Engl J Med 1999, 341(25):1906-1912.

17. Anonymous: Traditional Bush Medicines-An Aboriginal Pharmacopoeia. Richmond, Australia: Greenhouse Publications Pty Ltd; 1988:385-387.

18. Sagrawat H, Mann AS, Kharya MD: Pharmacological potential of Eugenia jambolana: A review. Pharmacogn Mag 2006, 2(6):96.

19. Leslie T: The Healing Power of Rainforest Herbs. Garden City Park, NY: Square One Publishers, Inc; 2005.

20. Sathiyanarayanan L, Arulmozhi S: Mucuna pruriens Linn. - A comprehensive review. Pharmacogn Rev 2007, 1(1):157-162.

21. Chauhan N, Dixit V: Antihyperglycemic activity of the ethanolic extract of Curculigo orchioides Gaertn. Pharmacogn Mag 2007, 3(12):237.

22. Awasthi L, Verma H: Boerhaavia diffusa-A wild herb with potent biological and antimicrobial properties. Asian-Agrihistory 2006, 10:55-68.

23. Palombo EA, Semple SJ: Antibacterial activity of traditional Australian medicinal plants. J Ethnopharmacol 2001, 77(2-3):151-157.

24. O'Connell J, Latz P, Barnett P: Traditional and modern plant use among the Alyawara of central Australia. Econ Bot 1983, 37(1):80-109.

25. Reid EJ, Betts TJ: Records of Western Australian plants used by Aboriginals as medicinal agents. Planta Med 1979, 36(2):164-173. 
26. Webb $\sqcup$ : The use of plant medicines and poisons by Australian Aborigines. Mankind 1969, 7:137-146.

27. Latz PK: Bushfires \& bushtucker: Aboriginal plant use in Central Australia. Alice Springs: IAD Press; 1995

28. Pari L, Amarnath Satheesh M: Antidiabetic activity of Boerhaavia diffusa L.: effect on hepatic key enzymes in experimental diabetes. J Ethnopharmacol 2004, 9(1):109-113.

29. Madhavan V, Joshi R, Murali A, Yoganarasimhan S: Antidiabetic Activity of Curculigo Orchioides. Root Tuber. Pharm Biol 2007, 45(1):18-21.

30. Grover JK, Vats V, Rathi SS: Anti-hyperglycemic effect of Eugenia jambolana and Tinospora cordifolia in experimental diabetes and their effects on key metabolic enzymes involved in carbohydrate metabolism. J Ethnopharmacol 2000, 73(3):461-470.

31. Teixeira CC, Pinto LP, Kessler FHP, Knijnik L, Pinto CP, Gastaldo GJ, Fuchs FD: The effect of Syzygium cumini (L.) skeels on post-prandial blood glucose levels in non-diabetic rats and rats with streptozotocin-induced diabetes mellitus. J Ethnopharmacol 1997, 56(3):209-213.

32. Devgun M, Nanda A, Ansari SH: Pterocarpus marsupium Roxb.-A Comprehensive Review. Pharmacogn Rev 2010, 3(6):359.

33. Katzenschlager R, Evans A, Manson A, Patsalos PN, Ratnaraj N, Watt $H_{\text {, }}$ Timmermann L, Van der Giessen R, Lees AJ: Mucuna pruriens in Parkinson's disease: a double blind clinical and pharmacological study. J Neurol Neurosurg Psychiatry 2004, 75(12):1672-1677.

34. Abesundara K, Matsui T, Matsumoto K: Alpha-glucosidase inhibitory activity of some Sri Lanka plant extracts, one of which, Cassia auriculata, exerts a strong antihyperglycemic effect in rats comparable to the therapeutic drug acarbose. J Agric Food Chem 2004, 52(9):2541-2545.

35. Correia RTP, Mccue P, Vattem DA, Magalhaes M, Macedo GR, Shetty K: Amylase and Helicobacter pylori inhibition by phenolic extracts of pineapple wastes bioprocessed by Rhizopus oligosporus. J Food Biochem 2004, 28(5):419-434.

36. Kwon Yl, Apostolidis E, Shetty K: In vitro studies of eggplant (Solanum melongena) phenolics as inhibitors of key enzymes relevant for type 2 diabetes and hypertension. Bioresour Technol 2008, 99(8):2981-2988.

37. Loizzo MR, Saab AM, Tundis R, Menichini F, Bonesi M, Piccolo V, Statti GA, de Cindio B, Houghton PJ: In vitro inhibitory activities of plants used in Lebanon traditional medicine against angiotensin converting enzyme (ACE) and digestive enzymes related to diabetes. J Ethnopharmacol 2008, 119(1):109-116.

38. Apostolidis E, Kwon YI, Shetty K: Inhibitory potential of herb, fruit, and fungal-enriched cheese against key enzymes linked to type 2 diabetes and hypertension. Innovative Food Science \& Emerging Technologies 2007, 8(1):46-54.

39. Hogan S, Zhang L, Li J, Sun S, Canning C, Zhou K: Antioxidant rich grape pomace extract suppresses postprandial hyperglycemia in diabetic mice by specifically inhibiting alpha-glucosidase. Nutr Metab 2010, 7(1):71.

40. Singleton VL, Slinkard K: Total phenol analysis: automation and comparison with manual methods. Am J Enol Vitic 1977, 28:49-55.

41. Dixit $Y, \operatorname{Kar} A$ : Antioxidative activity of some vegetable peels determined in vitro by inducing liver lipid peroxidation. Food Res Int 2009, 42(9):1351-1354

42. Kwon Yl, Apostolidis E, Kim YC, Shetty K: Health benefits of traditional corn, beans, and pumpkin: In vitro studies for hyperglycemia and hypertension management. J Med Food 2007, 10(2):266-275.

43. Dudonneí Sp, Vitrac X, Coutie're P, Woillez M, Meírillon J-M: Comparative Study of Antioxidant Properties and Total Phenolic Content of 30 Plant Extracts of Industrial Interest Using DPPH, ABTS, FRAP, SOD, and ORAC Assays. J Agric Food Chem 2009, 57(5):1768-1774.

44. Fawole OA, Amoo SO, Ndhlala AR, Light ME, Finnie JF, Van Staden J: Antiinflammatory, anticholinesterase, antioxidant and phytochemical properties of medicinal plants used for pain-related ailments in South Africa. J Ethnopharmacol 2010, 127(2):235-241.

45. American Diabetes Association: Consensus: Type 2 diabetes in children and adolescents. Diabetes Care 2000, 23(3):381-389.

46. Kaufman FR: Type 2 Diabetes in Children and Young Adults: A New Epidemic. Clinical Diabetes 2002, 20(4):217-218.

47. Tiwari AK: Wisdom of Ayurveda in perceiving diabetes: Enigma of therapeutic recognition. Curr Sci 2005, 88(7):1043-1051.

48. Sunil C, Ignacimuthu S: In vitro and in vivo antioxidant activity of Symplocos cochinchinensis S. Moore leaves containing phenolic compounds. Food Chem Toxicol 2011, 49(7):1604-1609.
49. Moyo M, Ndhlala AR, Finnie JF, Van Staden J: Phenolic composition, antioxidant and acetylcholinesterase inhibitory activities of Sclerocarya birrea and Harpephyllum caffrum (Anacardiaceae) extracts. Food Chem 2010, 123(1):69-76.

50. Gorinstein S, Zachwieja Z, Katrich E, Pawelzik E, Haruenkit R, Trakhtenberg S, Martin-Belloso O: Comparison of the contents of the main antioxidant compounds and the antioxidant activity of white grapefruit and his new hybrid. Lebensm Wiss Technol 2004, 37(3):337-343.

51. Victorian Aboriginal Health Service: Aboriginal diet and nutrition. Better Health Channel 1999/2010,

52. Diamond J: The double puzzle of diabetes. Nature 2003, 423(6940):599-602

53. Mukherjee PK, Maiti K, Mukherjee K, Houghton PJ: Leads from Indian medicinal plants with hypoglycemic potentials. J Ethnopharmacol 2006, 106(1):1-28.

54. Apostolidis E, Kwon Yl, Shetty K: Potential of cranberry-based herbal synergies for diabetes and hypertension management. Asia Pac J Clin Nutr 2006, 15(3):433-441

55. Sabu MC, Kuttan R: Anti-diabetic activity of medicinal plants and its relationship with their antioxidant property. J Ethnopharmacol 2002, 81(2):155-160.

doi:10.1186/1472-6882-12-77

Cite this article as: Gulati et al.: Enzyme inhibitory and antioxidant activities of traditional medicinal plants: Potential application in the management of hyperglycemia. BMC Complementary and Alternative Medicine 2012 12:77.

\section{Submit your next manuscript to BioMed Central and take full advantage of:}

- Convenient online submission

- Thorough peer review

- No space constraints or color figure charges

- Immediate publication on acceptance

- Inclusion in PubMed, CAS, Scopus and Google Scholar

- Research which is freely available for redistribution 